\title{
PENGARUH PENGGUNAAN MEDIA PERMAINAN SCRABBLE TERHADAP KETERAMPILAN MENULIS TEKS PROSEDUR SISWA KELAS X SMA TUGU IBU, DEPOK, JAWA BARAT
}

\author{
Mu'thia Mubasyira $^{1)}$ dan Sigit Widiyarto ${ }^{2)}$ \\ Universitas Indraprasta PGRI \\ muthia.mubasyira@yahoo.com ${ }^{l)}$ dan sigit.widiyanto372@gmail.com ${ }^{21}$
}

\begin{abstract}
Abstrak
Peneliti ini dilakukan di kelas kontrol dan kelas eksperimen. Pada kelas eksperimen, peneliti menggunakan media scrabble sebagai media pembelajaran. Hasil penelitian ini ditemukan bahwa anak lebih antusias dan aktif belajar di kelas. Penggunaan media permainan scrabble dapat membantu tercapainya tujuan pembelajaran. Terdapat perbedaan rata-rata pada kelas kontrol dan kelas eksperimen. Rata-rata kelas kontrol sebesar 29,4, sedangkan kelas eksperimen sebesar 82,4. Adapun kesimpulan dari penelitian ini adalah terdapat pengaruh sebesar $17 \%$ antara kelas yang menggunakan media permainan scrabble dan kelas yang tidak menggunakan media permainan.
\end{abstract}

Kata Kunci: permainan, scrabble, menulis, prosedur.

\begin{abstract}
This research is done in control class and experiment class. On the experiment class, the researchers uses scrabble media as learning media. The result of this reserach is found that students turn to be more antusiantic and active in learning in the class by using this media. The usage of scrabble game is able to help them to reach the aim of the learning. There is a different on rate between control class and experiment class. The rate on control class is 29,4 meanwhile on experiment class is 82,4 . The conclusion of this research is there is significant influence as much as $17 \%$ between the class that uses scrabble media game and the one which is not.

Keywords: game, scrabble, writing, procedure.
\end{abstract}

\section{PENDAHULUAN}

Manusia dibekali dengan akal dan pikiran yang dapat digunakan untuk berkarya. Tidak hanya dalam bertindak namun juga berbahasa. Bahasa merupakan alat berkomunikasi yang mengandung muatan pesan. Bahasa yang dapat dipakai untuk berkomunikasi tidak hanya bahasa nasional ataupun bahasa daerah namun juga bahasa Inggris sebagai bahasa Internasional.

Bahasa Inggris merupakan salah satubahasa asing di Indonesia yang wajibdikuasai dan diajarkan di sekolah formaldari usia 6-18 tahun. Untuk tingkatan SD antara usia 6-12 tahun, pembelajaranbahasa Inggris masuk kedalam matapelajaran muatan lokal. Sedangkan utnuk tingkat SMP yang berusia 12-15 tahun,mata pelajaran bahasa Inggris sudahmerupakan mata pelajaran wajib yangharus dipelajari dan dikuasai oleh siswa mata pelajaran bahasa Inggris merupakan salah satu bahasa yang dapat digunakan secara luas dalam setiap aspek kehidupan seperti ilmu pengetahuan dan pendidikan.

Kemampuan untuk meningkatkan daya ingat anak perlu diasah, sehingga otak dapat mempengaruhi hasil akhir yang dicapai. Mengasah otak adalah 
cara untuk meningkatkan kualitas kecerdasan dan pikiran dari seseorang. Biasanya anak-anak yang sedang tumbuh berkembang butuh sekali untuk mengasah otak mereka sebab anak-anak yang sedang tumbuh berkembang mudah sekali untuk di asah otaknya maka dari itu anak-anak yang sedang tumbuh berkembang itu hendaknya disuguhi dengan media-media untuk membantu peserta didik meningkatkan kemampuan berbahasa Inggris. Salah satu media untuk mengasah otak adalah melalui penggunaan media permainan scrabble.

Scrabble merupakan sebuah media yang berbentuk permainan dengan fungsi untuk mengasah otak atau menstimulasi perkembangan otak. Scrabble ini juga merupakan permainan berbentuk papan dan cara bermainnya dengan menyusun kata yang memiliki makna. Dengan permainan yang mengasah otak ini maka secara tidak sengaja peserta didik akan meningkatkan penguasaan kosakata yang kemudian dapat digunakan dalam merangkai kalimat bahkan paragraf melalui kegiatan menulis dalam bahasa Inggris.

Dalam berbahasa Inggris, ada empat keterampilan yang wajib dikuasai, yaitu: menulis (writing), membaca (reading), mendengarkan (listening) dan berbicara (speaking). Dari keempat keterampilan ini, menulis merupakan keterampilan yang paling sulit karena mengandung unsur-unsur yang sangat kompleks dan membutuhkan banyak keahlian dan kreatifitas apalagi dalam berbahasa Inggris.

Bram (2002:7) berpendapat bahwa: "In principle, to write means to try to produce or reproduce written message." Dengan demikian maka pada keterampilan menulis dibutuhkan pengalaman dan pengetahuan tentang berbagai macam tulisan atau genre salah satunya adalah teks prosedur. Teks prosedur merupakan salah satu genre dalam bahasa Inggris yang memberikan petunjuk tentang bagaimana melakukan suatu tindakan misalnya bagaimana cara membuat resep masakan, bagaimana cara menggunakan alat dan lain sebagainya. Dalam membuat teks prosedur, peserta didik selain memerlukan pengetahuan tentang struktur paragraf yang terdiri dari tujuan (goal), bahan-bahan (materials) dan langkah-langkah (steps), peserta didik juga memerlukan pengusaan kosakata yang salah satunya dapat diasah melalui media permainan scrabble. Oleh sebab itu, penelitian ini mencoba untuk memfokuskan diri dalam meneliti "Pengaruh Penggunaan Media Permainan Scrabble Terhadap Keterampilan Menulis Teks Prosedur Bahasa Inggris Siswa Kelas X SMA Tugu Ibu, Depok, Jawa Barat."

\section{TINJAUAN PUSTAKA}

\section{Pengertian Permainan Scrabble}

Dalam proses belajar mengajar, permainan merupakan kegiatan yang menarik bagi peserta didik. Sifat permainan tidak monoton, bahkan dapat menghilangkan rasa bosan. Permainan scrabble merupakan permainan yang sering dimainkan oleh seluruh kalangan tanpa memandang usia dan kultur budaya. Permainan menyusun kata di atas papan, dimainkan oleh 2 atau 4 orang agar mendapat skor nilai, berdasarkan nilai kata yang dibentuk panjang 15 baris dan 15 kolom. Permainan ini dapat meningkatkan kemampuan kosa kata dengan mengingat satu per satu kata yang disesuaikan dengan urutan baik baris maupun kolom maka siswa akan lebih tertarik untuk terus memecahkan kata demi kata. 
Menurut Kimpraswil mengatakan bahwa permainan adalah usaha olah diri (olah pikiran dan olah fisik) yang sangat bermanfaat bagi peningkatan dan pengembangan motivasi, kinerja, dan prestasi dalam melaksanakan tugas dan kepentingan organisasi dengan lebih baik. Cara main dan strategi main tidak terlalu rumit. Sejumlah sekolah telah menggunakan scrabble sebagai selingan dalam pembelajaran bahasa Inggris, khususnya dalam meningkatkan kapasitas kosakata pelajar. Melalui scrabble, pembelajaran kosakata bisa berlangsung lebih menyenangkan dan lebih mudah diserap. Bila melihat perbandingan antara pemakain srabble dengan permainan lain,permaianan ini lebih banyak menyerap kosakata baru.

Berdasarkan paparan di atas maka dapat disimpulkan bahwa permainan scrabble merupakan permainan olah kata bahasa Inggris dengan teknik dan aturan main tertentu.

\section{Manfaat Permainan Scrabble}

Adapun manfaat permainan scrabble adalah sebagai berikut: (1) Secara kognitif dengan tujuan agar peserta didik mampu meningkatkan kemampuan mengingatnya, (2) Motorik dengan tujuan agar peserta didik mampu mengkoordinasikan anggota tubuh seperti tangan sehingga mereka lebih terampil dalam menjalankan motorik halus dan kasar, (3) Logika dengan tujuan agar peserta didik mampu berpikir secara tepat dan teratur sehingga mereka lebih cepat mengambil keputusan, (4) Emosional/Sosial dengan tujuan agar peserta didik mampu menjalankan interpersonal skill sehingga mereka memiliki kesabaran dan lebih berhati-hati dalam bertindak, (5) Kreatif dengan tujuan agar peserta didik mampu menghasilkan ide melalui olah huruf menjadi kata.

\section{Aturan Permainan Scrabble}

Adapun aturan permainan scrabble sebagai berikut:

1. Tetapkan dulu pokok bahasan yang akan dipakai dalam permainan.

2. Letakkan biji-biji huruf semuanya dengan menghadap ke bawah dan aduklah.

Kemudian untuk menentukan siapa yang main lebih dulu, tiap peserta mengambil sebuah biji huruf. Siapa yang mendapatkan huruf $A$ atau terdekat dengan huruf A mendapatkan kesempatan sebagai pemain pertama. Kembalikan bijibiji huruf tersebut dan aduk kembali. Kini tiap pemain mengambil 8 biji huruf dan letakkan pada rak plastik di hadapannya.

3. Dengan memakai biji-biji tersebut, dalam waktu tertentu, pemain pertama membentuk sebuah kata di atas papan. Kata itu dapat terletak dari kiri ke kanan atau dari atas ke bawah. Asalkan sebuah huruf itu melewati di tengah papan. Sebagai catatan bji huruf tersebut tidak di izinkan terletak secara diagonal.

4. Pemain itu menyelesaikan gilirannya dengan menghitung dan mengumumkan jumlah angka yang dicapainya pada giliran itu. Ia kemudian dapat mengambil pula biji-biji huruf baru sebanyak yang telah ia pergunakan. Dengan demikian ia tetap mempunyai 8 biji huruf di tangan.

5. Giliran berputar searah jarum jam ke pemain kedua dan begitu seterusnya. Masing-masing pemain diberi kesempatan satu menit untuk merangkai kata. Giliran selanjutnya menambahkan sebuah atau lebih biji-biji huruf baru. Arahkan kata harus tetap ke kanan dan tegak lurus ke bawah. Sebuah kata yang lengkap harus terbentuk. 
6. Kata baru dapat dibentuk dengan:

a. Menambahkan satu atau lebih huruf pada satu kata atau huruf yang telah berada di atas papan.

b. Menaruh huruf-huruf secara bersilang pada suatu kata atau huruf yang telah berada di atas papan.

c. Menempatkan sebuah kata secara sejajar dengan suatu kata yang telah ada di atas papan, sedemikian rupa sehingga huruf yang berdampingan membentuk kata yang lengkap.

d. Menyisipkan sebuah huruf atau lebih di antara kata-kata yang telah ada di papan, sehingga rangkaian huruf yang terbentuk kedua arah merupakan huruf yang lengkap dan bermakna.

7. Beri tanda biji huruf yang dapat digeser atau dipindahkan setelah ditaruh di atas papan.

8. Biji huruf yang kosong dapat dipergunakan untuk mengganti huruf yang dikehendaki. Pemain tersebut harus menyatakan huruf apa yang diganti dan setelah itu tak dapat diubah selama permainan berlangsung.

9. Tiap pemain dapat menggunakan gilirannya untuk mengganti sebuah ataupun semua biji hurufnya itu dengan menghadapkan ke bawah dan mengambil biji-biji huruf baru dalam jumlah yang sama. Kemudian mencampur baurkan biji-biji huruf tersebut. Ia kemudian dengan tenang menanti girilan selanjutnya untuk bermain.

10. Semua kata yang terdapat dalam kamus dapat dipergunakan kecuali nama-nama khusus, yang lazimnya diawali huruf besar, singkatansingkatan, tanda hubung. Periksalah dengan kamus untuk mencocokan benar tidaknya cara dan menulis suatu huruf yang diragukan. Tiap kata dapat diragukan dan minta diperiksa sebelum tiba giliran pemain selanjutnya. Jika ternyata kata tersebut tidak dapat diterima, si pemain dapat mengambil kembali biji-biji hurufnya dan kehilangan giliran main tersebut.

11. Permainan berlangsung terus sampai semua biji huruf habis diambil dan slah seorang pemain telah memakai semua biji-biji hurufnya sehingga semua kemungkinan telah dicoba dengan hasil nihil sampai dengan tidak dapat merangkai huruf kembali.

\section{Pengertian Menulis}

Menulis (writing) merupakan kegiatan sehari-hari. Menulis adalah bagian dari komunikasi selain mendengarkan listening (mendengarkan), membaca (reading), dan berbicara (speaking) saat berinteraksi atau bergaul dengan orang lain. Nurgiyantoro (2001:271) mengatakan bahwa menulis merupakan suatu keterampilan berbahasa yang aktif, produktif, kompleks dan terpadu yang berupa pengungkapan dan yang menuntut penulis untuk menguasai berbagai unsur di luar kebahasaan itu sendiri yang akan menjadi ini dalam suatu tulisan. Dengan demikian, menulis pada hakikatnya adalah komunikasi tulisan. Pesan yang disampaikan bisa berupa informasi, gagasan, pemikiran, ajakan dan sebagainya. Tapi jangan dibayangkan bahwa menulis itu susah. Buah pikiran tersebut dapat berupa pengalaman, pendapat, pengetahuan, perasaan dampak dari gejolak kalbu seseorang.

Menurut Yunus (2002:1-3) berpendapat bahwa menulis merupakan kegiatan komunikasi verbal yang berisi penyampaian pesan dengan menggunakan tulisan sebagai mediumnya. Pesan yang dimaksud di 
sini adalah isi atau muatan yang terkandung dalam tulisan, sedangkan tulisan pada dasarnya adalah rangkaian huruf yang bermakna dengan segala kelengkapan lambang tulisan seperti ejaan dan pungtuasi. Dengan demikian, menulis merupakan salah satu bentuk penggunakan bahasa, disebut keterampilan berbahasa, yang melihat empat unsur, yaitu penulis sebagai penyampaian pesan atau isi tulisan, saluran atau medium tulisan, dan pembaca sebagai penerima pesan. Menulis juga merupakan suatu proses, yaitu proses penulisan. Hal ini berarti melakukan kegiatan tersebut dalam beberapa tahap, yaitu tahap pra penulisan, tahap penulisan, dan tahap revisi. Tulisan yang baik dapat menghubungkan antara penulis sebagai pemberi pesan dan pembaca sebagai penerima pesan.

De porter (2000:179) mengatakan bahwa menulis adalah aktifitas seluruh otak yang menggunakan belahan otak kanan (emosional) dan belahan otak kiri (logika). Aktifitas otak kanan untuk keterampilan menulis meliputu perencanaan, outline, tata bahasa, penyuntingan, penulisan kembali, penelitian dan tanda baca, sedangkan aktifitas otak kiri, yaitu semangat, spontanitas, emosi, warna, imajinasi, gairah unsur baru, dan kegembiraan. Aktifitas dalam penulisan otak kiri dan otak kanan harus bekerja sama.

Menurut Hermowo (2008:11) mengungkapkan bahwa ada konsep dan teknik menulis bernama brain-based writing (menulis sesuai cara kerja otak). Berikut beberapa teknik menulis yang sesuai dengan cara kerja otak yang dapat di praktekan dalam kehidupan sehari-hari, yaitu:

Pertama, menulis dengan menggunakan otak kanan terlebih dahulu dan baru kemudian menggunakan otak kiri. Menggunakan otak kanan terlebih dahulu karena otak kanan ini menyukai kebebasan dan tidak menyukai hal-hal yang berurutan dan tertib. Sangat berbeda jika kita mengawali menulis dengan menggunakan otak kiri, akan sibuk dengan aturan dan akan memulai menulis secara teratur, misalnya mencari kata pembuka yang tepat. Hal ini dikarenakan sifat otak kiri memang tertib dan logis. Gunakan otak kanan terlebih dahulu ketika mengawali menulis sehingga seluruh badan mental tulisan dapat dikeluarkan dan merasa lega.

Kedua, menulis dengan memanfaatkan kecerdasan majemuk (multiple intelligences) berpikir secara bergerak (body smart).

Ketiga, menulis menggunakan kecerdasan emosi. Berpikir secara baik dan benar untuk menetapkan jenis emosi. Seperti yang dikatakan sebelumnya, menulis merupakan keterampilan bahasa yang paling sulit dipelajari dibandingkan dengan keterampilan berbahaya lainnya, seperti menyimak, berbicara dan membaca.

Aktivitas menulis merupakan suatu bentuk manifestasi kemampuan berbahasa yang paling akhir dikuasai siswa setelah kemampuan mendengarkan, berbicara dan membaca. Dibanding tiga kemampuan berbahasa yang lain, menulis lebih sulit dikuasai (Nurgiantoro, 2008:294). Lebih lanjut dijelaskan bahwa kemampuan menulis menghendaki penguasaan berbagai unsur kebahasaan dan unsur di luar bahasa itu sendiri yang akan menjadi isi tulisan.

Berdasarkan pendapat di atas maka dapat diambil kesimpulan bahwa menulis merupakan kegiatan untuk berkomunikasi non verbal yang dapat direalisasikan menurut kecenderungan dominasi kerja otak setiap individu. 


\section{METODE PENELITIAN}

\section{TEMPAT PENELITIAN}

Depok merupakan sebuah kota yang terletak di Provinsi Jawa Barat yang terdiri dari 11 kecamatan, yaitu: Beji, Pancoran Mas, Cipayung, Sukmajaya, Cilodong, Limo, Cinere, Cimanggis, Tapos, Sawangan dan Bojong Sari. Salah satu kecamatan dipilih secara acak, yaitu kecamatan Sukmajaya. Pada kecamatan Sukmajaya terdapat beberapa sekolah menengah atas. Agar penelitian ini lebih fokus maka sekolah menengah atas swasta yang berakreditasi A bernama SMA Tugu Ibu dipilih sebagai lokasi penelitian ini. Sekolah ini berlokasi di Jalan Sentosa No. 2, Depok II Tengah.

\section{METODE PENELITIAN Jenis Penelitian}

Metode yang digunakan dalam penelitian ini adalah metode eksperimen. Menurut Sugiyono (2011:72) "Metode eksperimen adalah sebuah metode penelitian yang digunakan untuk mencari pengaruh perlakuan tertentu terhadap yang lain dalam kondisi terkendali." Metode ini merupakan satu-satunya metode penelitian yang menguji secara benar hipotesis yang menyangkut hubungan kausal (sebab akibat). Dalam penelitian eksperimen ini, peneliti melakukan pengukuran sebanyak satu kali yaitu sesudah perlakuan. Jenis penelitian ini adalah penelitian kuantitatif.

\section{Desain Penelitian}

Berdasarkan pada metode yang di gunakan dalam penelitian, yaitu metode eksperimen post-test design maka desain eksperimen yang digunakan adalah sebagai berikut:

Tabel 3.1 Rancangan Penelitian

\begin{tabular}{|c|c|c|}
\hline KE & X & Y1 \\
\hline KK & - & Y2 \\
\hline
\end{tabular}

Keterangan:

$\mathrm{KE}$ : Kelas Eksperimen

KK : Kelas Kontrol

$\mathrm{X}$ : treatment (perlakuan), berupa penguasaan keterampilan berbicara dengan menggunakan permainan word tail

Y1: Hasil pembelajaran pada kelas eksperimen setelah treatment (perlakuan)

Y2: Hasil pembelajaran pada kelas kontrol tanpa diberikan treatment (perlakuan)

\section{POPULASI DAN SAMPEL \\ Populasi Penelitian}

Populasi menurut Sugiyono (2010:61) "Populasi adalah wilayah generalisasi yang terdiri atas: objek/subjek yang mempunyai kualitas dan karakteristik tertentu yang ditetapkan oleh peneliti untuk dipelajari dan kemudian ditarik kesimpulannya." Desain yang digunakan dalam penelitian ini adalah post-test (test akhir) dalam satu kelas eksperimen. Penelitian ini termasuk penelitian dengan jenis kuantitatif.

Menurut Arikunto (2006:173) "Populasi adalah keseluruhan subjek penelitian. Populasi dalam penelitian ini adalah sebagai berikut:

1. Populasi Target

Populasi target pada penelitian ini adalah siswa kelas X SMA Tugu Ibu, Depok, Jawa Barat.

2. Populasi Terjangkau

Populasi terjangkau pada penelitian ini adalah siswa kelas $\mathrm{X}$ semester genap SMA Tugu Ibu, Depok, Jawa Barat. Dipilih 2 kelas yang satunya tidak mendapatkan treatment disebut dengan kelas konvensional sedangkan yang lainnya diberi treatment disebut dengan kelas kontrol. 


\section{Sampel Penelitian}

Sampel menurut Arikunto (2006:174) adalah "Bagian dari populasi (sebagian atau wakil populasi yang diteliti) yang bertujuan untuk menggeneralisasikan hasil penelitian, yakni mengangkat kesimpulan penelitian sebagai sesuatu yang berlaku bagi populasi." Jadi yang maksud dengan sampel adalah perwakilan dari populasi yang bertujuan untuk mengetahui hasil rata-rata dari susatu objek tertentu.

Sampel ditetapkan dari siswa kelas X semester genap SMA Tugu Ibu, Depok, Jawa Barat yang menjadi kelas ekperimen dengan jumlah responden sebanyak 30 siswa menggunakan media permainan scrabble sedangkan 30 siswa menggunakan metode konvensional. Sehingga total sampel yang diambil oleh peneliti adalah 60 siswa.

\section{METODE PENGUMPULAN DATA}

Dalam metode pengumpulan data penulis menggunakan metode eksperimen tentang belajar bahasa Inggris meggunakan media permainan scrabble dan metode konvensional.

\section{VARIABEL PENELITIAN}

Variabel atau objek penelitian ini terdiri atas dua variabel, yaitu variabel bebas dan variabel terikat. Variabel bebas (X) dan variabel terikat (Y) dalam penelitian ini adalah:

1. Variabel Bebas (X): Penggunaan Media Permainan Scrabble

2. Variabel Terikat (Y): Keterampilan Menulis Teks Prosedur Bahasa Inggris siswa.

\section{SUMBER DATA}

Arikunto (2006:129) menjelaskan yang dimaksud dengan sumber data adalah subjek dari mana data dapat diperoleh. Sumber data yang digunakan berasal dari sumber primer. Yang dimaksud sumber primer menurut Suseno dkk (2013:18) adalah "Data yang dapat dikumpulkan langsung oleh peneliti melalui pihak yang diteliti," yaitu siswa kelas X SMA Tugu Ibu, Depok, Jawa Barat.

\section{TEKNIK PENGUMPULAN DATA}

Riduwan (2012: 69) menjelaskan "Metode pengumpulan data adalah teknik atau cara-cara yang dapat digunakan oleh peneliti untuk mengumpulkan data."

Teknik pengumpulan data yang peneliti gunakan dalam penelitian ini yaitu melakukan dua perlakuan yang berbeda terhadap sampel dari kelas X-1 dan siswa kelas X-2 yang berjumlah 60 siswa. Maka siswa kelas X-1 akan dijadikan kelas eksperimen dengan menggunakan media permainan scrabble dan siswa kelas X-2 sebagai kelas kontrol. Pengumpulan data dilakukan dengan membandingkan nilai kelas eksperimen dan nilai kelas kontrol terhadap keterampilan mereka dalam menulis teks prosedur bahasa Inggris berupa worksheet.

\section{INSTRUMEN PENELITIAN Definisi Konseptual}

Keterampilan menulis teks prosedur dalam bahasa Inggris merupakan keterampilan menulis salah satu genre yang bertujuan memberikan petunjuk tentang langkah, metode, dan cara dalam melakukan sesuatu yang memiliki struktur goal, materials, dan steps.

\section{Definisi Operasional}

Keterampilan menulis teks prosedur merupakan skor tentang bagaimana siswa mampu menulis karangan prosedur dengan memperhatikan urutan langkah-langkah yang benar dan terstruktur. Pengambilan skor dilakukan dengan 
menggunakan worksheet untuk post-test yang merupakan hasil belajar yang didapatkan peserta didik setelah memperoleh treatment dengan menggunakan media permainan scrabble.

\section{Kisi-kisi Instrument.}

Berdasarkan definisi konseptual dan operasional di atas maka worksheet yang akan diberikan sebagai post test kepada peserta didik baik kelas kontrol maupun kelas eksperimen adalah berbentuk soal menyusun paragraf acak yang menguji keterampilan menulis karangan prosedur peserta didik.

\section{TEKNIK ANALISIS DATA \\ Teknik Analisis Deskriptif}

Arikunto (2012:239) menjelaskan bahwa: "Data kuantitatif yang dikumpulkan dalam penelitian korelasional, komparatif, atau eksperimen diolah dengan rumus-rumus statistik yang sudah disediakan, baik secara manual maupun dengan menggunakan jasa komputer".

Analisa yang dilakukan dalam deskripsi data meliputi gambaran umum responden, distribusi frekuensi, menyajikan data dalam bentuk tabel dan grafik (histogram dan poligon frekuensi), menghitung tendensi sentral (rata-rata) dan menghitung ukuran penyebaran (simpangan baku).

\section{Uji Persyaratan Data}

1. Teknik Pengujian Normalitas

Menguji normalitas data menggunakan uji Lilliefors. Dengan ketentuan nilai $L_{\text {hitung }}<L_{\text {tabel }}$, data berasal dari populasi normal. Rumus Lilliefors adalah sebagai berikut:

$$
\begin{aligned}
& L_{0}= \\
& F(Z i)-S(Z i)
\end{aligned}
$$

2. Teknik Pengujian Homogenitas

Persyaratan agar pengujian homogenitas dapat dilakukan ialah apabila kedua datanya telah terbukti berdistribusi normal. Uji homogenitas atau uji $F_{\text {hitung }}$, yaitu dengan mencari varian atau standar deviasi dari variabel $\mathrm{X}$ dan $\mathrm{Y}$ terlebih dahulu.

\section{Teknik Pengujian Hipotesis Penelitian}

Untuk mengetahui adanya pengaruh penggunaan media permainan scrabble terhadap keterampilan menulis teks prosedur bahasa Inggris siswa kelas X SMA Tugu Ibu, Depok, Jawa Barat. Responden diberikan test berupa test tertulis dan hasil tes akan diuji dengan "Uji t" pada taraf signifikasi $\alpha=0,05$ dengan derajat kebebasan $\mathrm{n} 1+\mathrm{n} 2-2$.

Kriteria pengujian hipotesis :

Jika thitung $<\mathrm{t}_{\text {tabel }}$ maka $\mathrm{H}_{0}$ diterima $\mathrm{H}_{\mathrm{a}}$ ditolak.

Jika thitung $>\mathrm{t}_{\text {tabel }}$ maka $\mathrm{H}_{0}$ ditolak $\mathrm{H}_{\mathrm{a}}$ diterima.

\section{HIPOTESIS PENELITIAN}

Hipotesis penelitian ini adalah

1. Terdapat perbedaan yang signifikan antara kelompok eksperimen dan kelompok kontrol

2. Tidak terdapat perbedaan yang signifikan antara kelompok eksperimen dan kelompok kontrol.

Dalam bahasa statistik maka:

$H_{0}: \mu_{1}=\mu_{2}$

$H_{1}: \mu_{1}>\mu_{2}$

Dimana:

$\mu_{1:}$ nilai rata-rata untuk populasi kelas eksperimen

$\mu_{2:}$ nilai rata-rata untuk populasi kelas kontrol

\section{HASIL PENELITIAN DAN PEMBAHASAN}

\section{HASIL PENELITIAN}

Deskripsi data secara umum terdapat pada Bab IV dapat ditampilkan 
deskripsi statistic dari hasil pehitungan dan pengujian yang dilkukan dengan computer melalui program aplikasi
Statistic Product and Service Solution (SPSS) 21

Tabel. Deskripsi data Penelitian

\section{Descriptives}

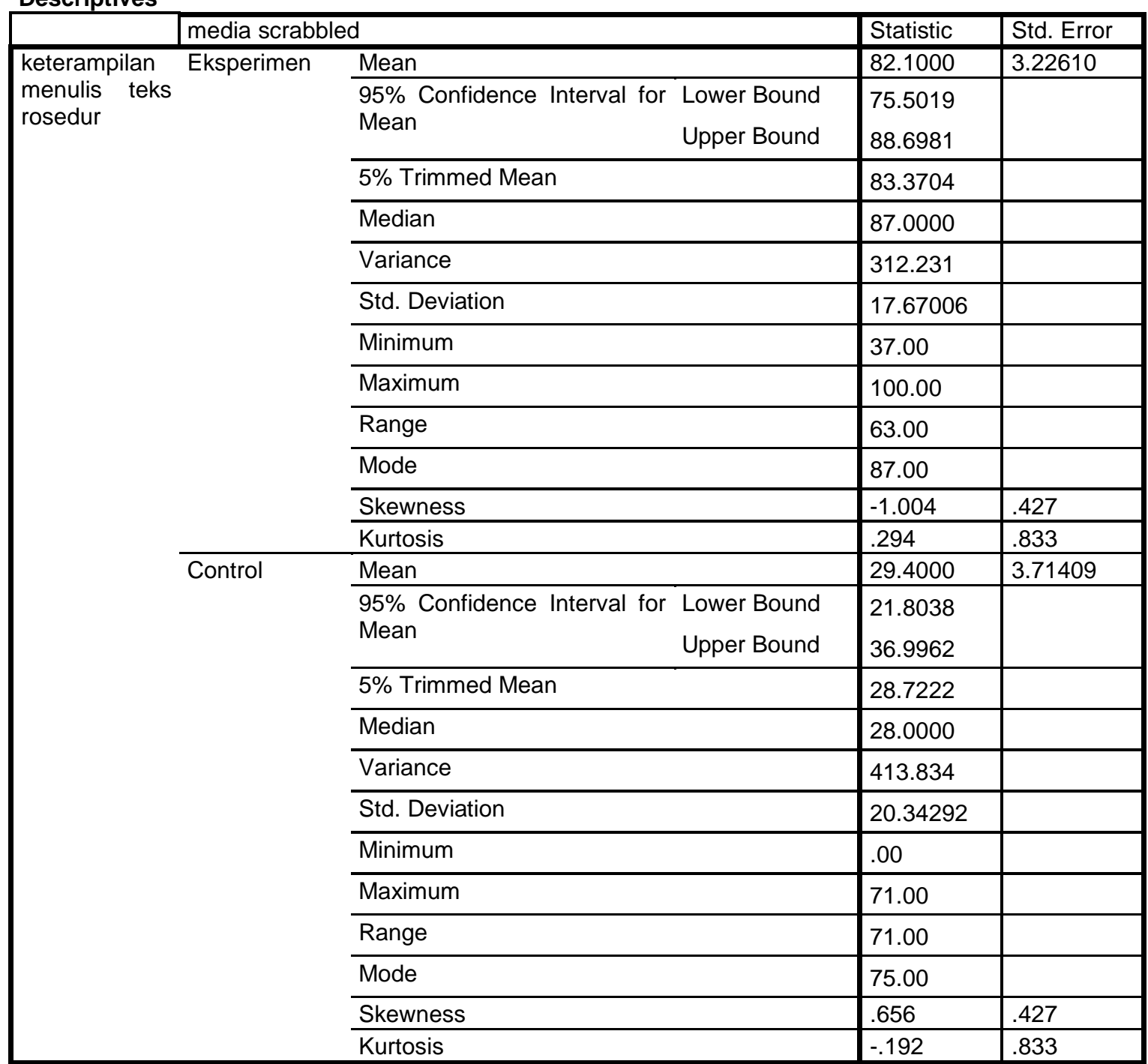

Jumlah responden sebanyak 30 siswa.Nilai yang diperolehan dari hasil kelas control: Mean ( Rata rata) 29,4, standard deviasi 20,342, varians 413,834 , nilai maksimum 71 , minimum sebesar 0 , nilai mode 75 dan nilai tengah 28 .
Nilai yang diperoleh dari hasil kelas eksperimen adalah: Mean sebesar 82,10 , standad deviasi 17,67 , varians 31,22 , nilai maksimum 100 , nilai minimum 37, nilai mode 87 dan nilai tengah

87. 


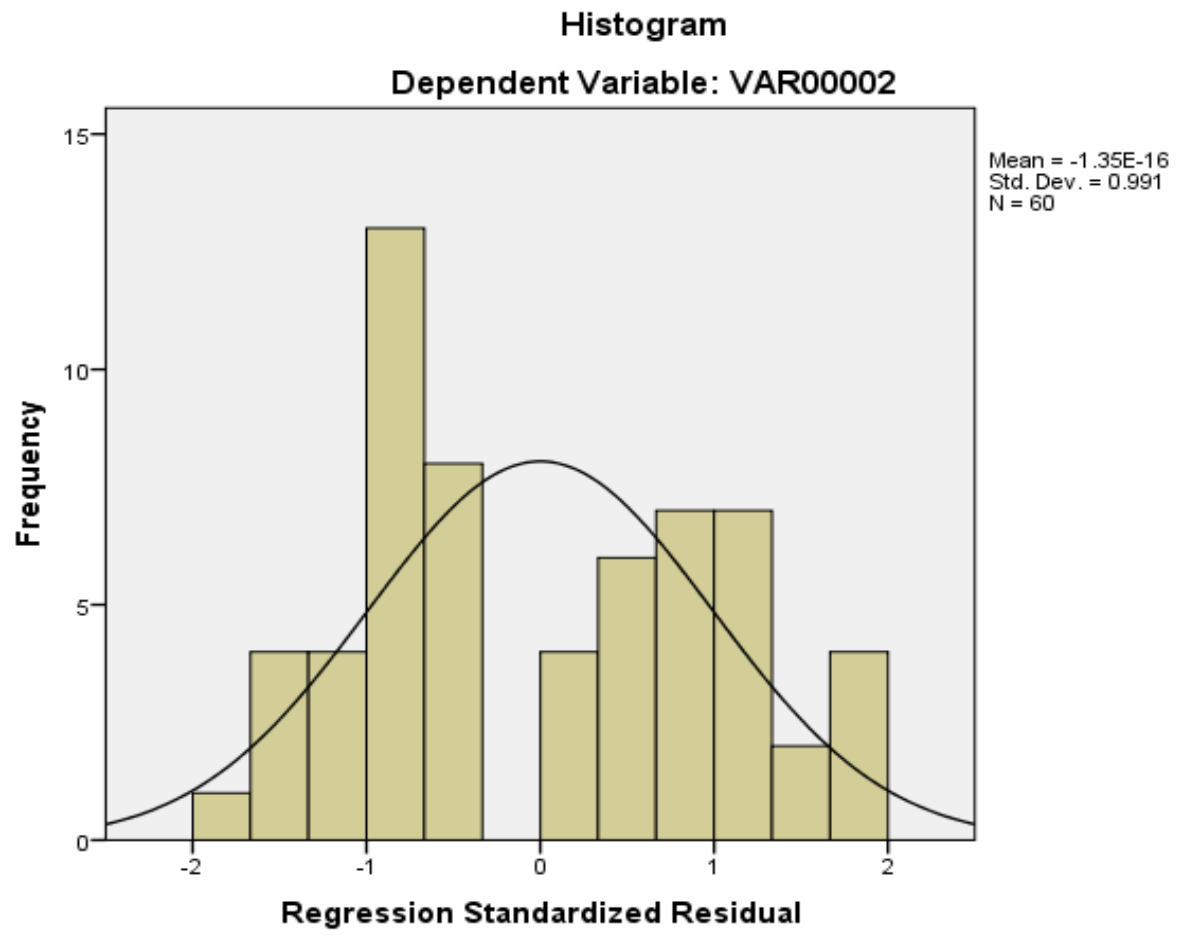

Gambar Kelas Kontrol

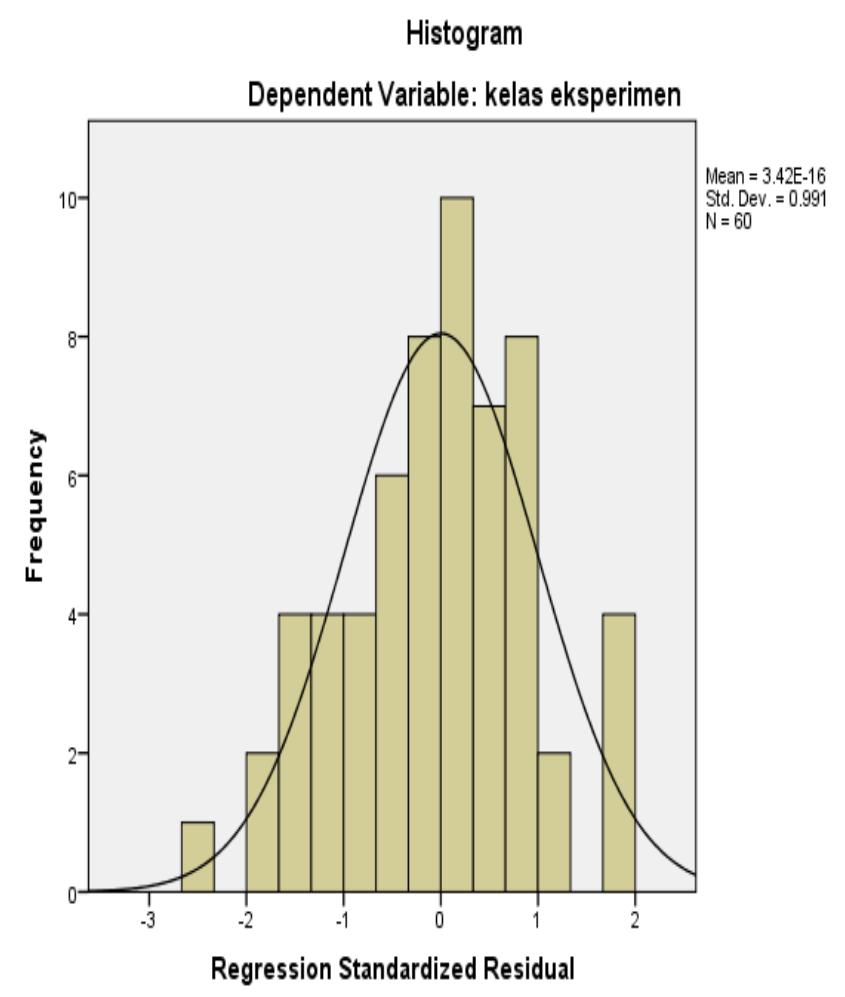

Gambar Histogram Kelas Eksperimen 


\section{Pengujian Persyaratan Analisis}

Pengujian Persyaratan analisis data yang dilakukan dalam penelitian ini adalah pengujian normalitas dan homogenitas

1. Pengujian Normalitas Data

Pengujian Normalitas data dapat uji melalui hipotesis berikut:

Ho $=$ data pada sampel berdistribusi normal

$\mathrm{H} 1$ = data pada sampel tidak berdistribusi normal

Berdasarkan perhitungan SPSS 21, jika $\mathrm{p}$-value (sig) $>0,05$ maka Ho diterima,yang mengandung arti data tersebut berdistribusi normal.

Jika nilai p-value (sig) adalah tertera pada kolom sig dalam tabel hasil perhitungan pengujian normalitas oleh program SPSS.

Pada tabel di bawah dapat terlihat Kolmogorov-Smirnov pada kolom Sig. sampel lebih besar dari 0,05, sehingga Ho diterima. Baik kelas kontrol dan eksperimen berdistribusi normal.

\begin{tabular}{|c|c|c|c|c|c|c|c|}
\hline & \multirow[b]{2}{*}{ media scrabbled } & \multicolumn{3}{|c|}{ Kolmogorov-Smirnova } & \multicolumn{3}{|c|}{ Shapiro-Wilk } \\
\hline & & Statistic & df & Sig. & Statistic & df & Sig. \\
\hline keterampilan menulis teks & eksperimen & .187 & 30 & .009 & .858 & 30 & .001 \\
\hline rosedur & Control & .194 & 30 & .006 & .907 & 30 & .012 \\
\hline
\end{tabular}

2. Pengujian Homogenitas

Pengujian Homogenitas menggunakan hipotesis sebagai berikut. Ho $=$ varians data homogeny

Tabel Hasil Pengujian Homogenitas

Test of Homogeneity of Variances

\begin{tabular}{|l|l|l|l|}
\hline Levene Statistic & $\mathrm{df1}$ & $\mathrm{df2}$ & Sig. \\
\hline .556 & 1 & 58 & .459 \\
\hline
\end{tabular}

Pada Tabel terlihat Sig 0,459 lebih besar dari 0,05 , sehingga Ho diterima, sehingga sampel tersebut dari populasi yang homogen.

\section{Tabel Nilai korelasi}

\section{Pengujian Hipotesis} pada table di bawah ini :

Paired Samples Correlations
\begin{tabular}{|ll|l|l|l|}
\hline \multicolumn{2}{|c|}{ kelas kontrol \& kelas } & $\mathrm{N}$ & Correlation & Sig. \\
\hline Psperimen & 30 & .226 & .229 \\
\hline
\end{tabular}

Pada tabel dapat dilihat nilai korelasi 0,226 yang berarti terdapat perbedaan yang cukup signifikan antara kelas kontrol dan eksperimen.
$\mathrm{H} 1$ = varians data tidak Homogen Jika P-Value (sig) > 0,05 maka Ho diterima,yang berarti sampel berasal dari populasi yang homogen.

Pengujian Hipotesis dapat dilihat

Kontrib usi sebesar 0,226 x 0,226 x $100 \%$ sebesar $5,12 \%$, sedangkan $94,88 \%$ dipengaruhi faktor lain. 


\section{Statistik Data Berpasangan}

Paired Samples Statistics

\begin{tabular}{|ll|l|l|l|l|}
\hline & Mean & N & Std. Deviation & Std. Error Mean \\
\hline Pair 1 & kelas control & 65.2000 & 30 & 20.42041 & 3.72824 \\
& kelas ksperimen & 82.5000 & 30 & 16.37229 & 2.98916 \\
\hline
\end{tabular}

Pada Tabel dapat diketahui ratarata kelas kontrol sebesar 65,2, sedangkan kelas eksperimen 82,5. Hal ini terdapat perbedaan rata rata,yang mengandung arti bahwa adanya peningkatan yang cukup tinggi dari kelas kontrol ke kelas eksperimen.

\section{PEMBAHASAN}

Hasil penelitian menunjuan bahwa pengaruh Media scrabbled cukup signifikan. Pemakaian media tersebut dapat meningkatkan kemampuan menulis teks prosedur. Peserta didik lebih memahami,jika sebelumnya sudah memiliki pengetahuan awal. Pengetahuan awal ini penting, jika tidak memahami siswa akan kurang mengerti dengan apa yang disampaikan oleh guru.

Pemakaian media scrabble banyak sekali memerlukan pengetahuan kosakata. Kosakata dapat membantu dalam pemahaman pembuatan kalimat.Siswa yang sering mengasah pengetahuan kosakata, maka akan memahami dalam penyususan kalimat teks prosedur dengan baik. Media scrabbled dapat mempengaruhi kemampuan menulis teks prosedur, untuk itu peranan media ini penting.

Media yang cocok bagi siswa dapat menumbuhkan pembelajaran yang menyenangkan.Siswa antusias mengikuti pelajaran di kelas.Guru terbantu dengan memakai media scrabbled.Kegiatan pembelajaran tersebut semakin mudah untuk mentransfer pelajaran kepada siswa di sekolah.
Media dapat berbuat lebih dari yang bias dilakukan oleh guru. Salah satu aspek yang harus diupayakan oleh guru dalam pembelajaran adalah siswa harus berperan aktif baik secara fisik, mental dan emosional. Menurut Jamal Ma'mur (143:2016). Guru juga dapat memperjelas pesan pembelajaran dan memberikan penjelasan yang konkrit.

\section{SIMPULAN}

Simpulan dari penelitian, pengaruh media Scrabbled terhadap kemampuan menulis teks prosedur sebagai berikut:

1. Terdapat perbedaan nilai rata-rata antara kelas kontrol dan Eksperiment.

2. Adanya peningkatan nilai kemampuan menulis teks prosedur

3. Terdapat pengaruh sebesar $17 \%$, antara pemakaian Media scrabbled dengan kemampuan menulis teks prosedur.

\section{DAFTAR PUSTAKA}

Arikunto. (2006). Managemen Pengajaran. Yogyakarta: Rineka Cipta.

Hermowo. (2008). Mengasah Otak Setajam Silet. Jakarta: Kaifa.

Nurgiyantoro, B. (2007). Teori Pengkajian Fiksi. Yogyakarta: UGM Press.

Potter, B. D. (2001). Quantum Learning Membiasakan Belajar Nyaman dan Menyenangkan. Jakarta: Mizan Publika. 
Riduwan, M. J. (2014). Tips Membangun Belajar di Sekolah. Jakarta. Diva Press.
Sugiyono. (2009). Memahami

Penelitian Kualitatif. Bandung: Pustaka Setia.

Yunus, S. (2016). Kompetensi Menulis Kreatif. Solo: Ghalia Indonesia. 